\title{
SATELLITE SNOW-COVER MONITORING IN THE QILIAN MOUNTAINS AND AN ANALYSIS FOR CHARACTERISTICS OF STREAM SNOW-MELT RUN-OFF IN THE HEXI REGION, GANSU, CHINA
}

\author{
by \\ Zeng Qunzhi, Zhang Shunying, Chen Xianzhang and Wang Jian \\ (Lanzhou Institute of Glaciology and Geocryology, Academia Sinica, Lanzhou, Gansu, \\ People's Republic of China)
}

\begin{abstract}
The images of NOAA/TIROS-N APT, AVHRR, and a few Landsat MSS obtained from 1980 to 1985 are analysed in this paper. It is found that the snow-cover distribution in Qilian Mountains is above $3700 \mathrm{~m}$ a.s.1. during winter to spring every year. There are two concentrations of snow cover. One is on Mount Leng Longling in the upper reaches of the Shiyang River and the other is located between Hala Lake and Mount Danghe Nanshan.

Based on preliminary investigations, it is known that the surface water resource in the Hexi region is $68.8 \times$ $10^{8} \mathrm{~m}^{3}$, of which about $24.8 \%$ is from glaciers and melting, and the snow-melt run-off is $7.63 \times 10^{8} \mathrm{~m}^{3}$, equal to $62.6 \%$ of the total amount of spring run-off.

The average value of $\mathrm{Cv}$ for spring run-off in the Shiyang River, Heihe River, and Shule River is 0.32 and the $\mathrm{Cv}$ value of snow-melt run-off in spring is 0.41 , about three times as much as that of the annual run-off in the Hexi region. A prediction model of spring snow-melt runoff at the Ying Louxia Hydrometric station in the Heihe River area can be constructed by using hydrometeorological data and snow-cover percentage for the Heihe River basin obtained from NOAA/TIROS-N APT, and AVHRR images. The prediction models (2) and (3) have been tested by the Water Resources Management Office of the Heihe River basin in the Zhangye and Flood Prevention Office of Gansu Province. The prediction accuracy is suitable for demands.
\end{abstract}

\section{INTRODUCTION}

The Qilian Mountains are located at the north-east edge of the Qinhai-Xizang Plateau (lat. $36^{\circ} 30^{\prime}-39^{\circ} 30^{\prime} \mathrm{N}$., long. $93^{\circ} 30^{\prime}-103^{\circ} \mathrm{E}$.), between the dry Hexi region and the Alashan Plateau in the north and the Qaidam basin and the Yellow River valley in the south, $850 \mathrm{~km}$ in length, $200-300 \mathrm{~km}$ in width and about $200000 \mathrm{~km}^{2}$ in area. About $30 \%$ of the whole mountain area is above $4000 \mathrm{~m}$ a.s.l.. Because of the high altitude and low air temperature, there are many glaciers in the Qilian Mountains. According to the statistics, there are 2859 glaciers with a total area of $1972.5 \mathrm{~km}^{2}$. The altitude of the snow line (north slope) rises westward from $4409 \mathrm{~m}$ in the east at Mount Leng Longling to $5075 \mathrm{~m}$ in the north-west Mount Qaidam. Also, the altitudes of the glacier termini rise from $4296 \mathrm{~m}$ in the east up to $5021 \mathrm{~m}$ in the north-west. The total amount of glacier-melt run-off per year in the Qilian Mountains is $11.56 \times 10^{8} \mathrm{~m}^{3}$, of which $9.46 \times 10^{8} \mathrm{~m}^{3}$ flows into the Hexi region, equal to $13.1 \%$ of the outlet surface run-off from the Qilian Mountains. In addition, there is a lot of seasonal snow cover in winter and spring in the Qilian Mountains providing snow-melt water; for example, the amount of snow-melt run-off in spring is as much as 7.64 $\times 10^{8} \mathrm{~m}^{3}$ in the Shiyang River, Heihe River, and Shule River areas, about $11.7 \%$ of total run-off. Based on preliminary investigations it is known that the surface-water resource in the Hexi region is $68.8 \times 10^{8} \mathrm{~m}^{3}$, of which about $24.8 \%$ is from glacier and snow melting. The uneven distribution of water resources in space and time is the main problem in water supply, especially in the spring (April-June), and agricultural growth in the Hexi region is affected by a lack of water in the spring.

Because most of meteorological and hydrometric stations in the Qilian Mountains are distributed along the valleys at a low altitude, the data cannot be representative of information on precipitation and snow-cover in the high mountains. So, it is necessary to carry out snow-cover dynamic monitoring on a large scale and snow-melt run-off forecasting in that region using satellite remote-sensing technology. In this paper, the authors intend to discuss the characteristics of variation in the spring run-off in the Hexi region and their relation to snow cover in the Qilian Mountains, taking the Heihe River as an example, by using remote-sensing techniques.

\section{DATA, METHODS AND ACCURACY OF ESTIMATIONS}

NOAA/TIROS-N APT, AVHRR, and a few Landsat MSS cloud-free images in 1980-85 were used as the basic data. By optical interpretation techniques, the extent of snow cover in the Qilian Mountains was determined. Snow cover in satellite images was transferred on to a topographic map (1: 150 000), using the Zoom Transfer Scope (ZTS); then the snow-cover area can be obtained by using a planimeter. Another method is as follows: snow cover in the satellite image was transferred on to a 1: 100000 scale topographic map, together with the elevation of the average seasonal snow line. The snow-cover area can be derived from an area-elevation curve for the Heihe River basin.

Bingou River, in the upper reaches of Heihe River was selected as a test basin for examining the dependability of snow-cover data derived from the methods mentioned above and for hydro-meteorological observations throughout the year, snow-cover surveys in the mountains and spectrum-reflectance measurement $(0.38-1.20 \mu \mathrm{m})$ from different objects on the subaerial surface. The elevation of the seasonal snow-cover line in the Bingou River area on 3 November 1983 was $3900 \mathrm{~m}$ and the area of snow cover above this altitude was measured as $53.27 \mathrm{~km}^{2}$ from the topographic map $(1: 50000)$, while it was $58.5 \mathrm{~km}^{2}$ in area from interpretation of NOAA/TIROS-N AVHRR images at $16.00 \mathrm{~h}$ on the same day. The value measured from images was $5.23 \mathrm{~km}^{2}$ or $9.8 \%$ greater than that by observation. This method is economical and efficient, although it is less accurate. To measure the snow-cover area in a basin using NOAA/TIROS-N AVHRR digital data (CCTs), first of all, geometric correction of the AVHRR images must be carried out. Then, statistics of the snow-cover percentage can be obtained. Using this method, the position error is no more than 0.5 pixel. The NOAA/TIROS-N AVHRR digital data (CCTs) cannot be obtained within $24 \mathrm{~h}$, although the accuracy is high, so it is not suitable for operational use. 


\section{DISTRIBUTION OF SNOW COVER IN THE QILIAN MOUNTAINS}

Seasonal snow cover in the Qilian Mountains is formed in early September and ends in early June the following year. September to October and April to June the following year are the main supply periods of seasonal snow cover. Under the control of the Mongolian high pressure in winter, the Qilian Mountains are rather dry and cold, and with less precipitation. By interpreting Landsat MSS images on 7 and 8 October 1975, it is known that the altitude of the seasonal snow line in early winter in the eastern Qilian Mountains, including Heihe River and Shiyang River, is about $3800 \mathrm{~m}$. Field observation shows that there is only fragmentary snow cover on shadow slopes and forest regions at an altitude of $3800 \mathrm{~m}$ in the upper reaches of the Heihe River in November. Between 3800 and $3900 \mathrm{~m}$ there is a discontinuous snow-cover zone; above $3900 \mathrm{~m}$, there is a continuous (stable) snow-cover area, where the depth of snow cover reaches $5-20 \mathrm{~cm}$. Based on an analysis of field-measurement data from 1983 to 1985 in the Bingou River test basin, within a certain range of altitude, snow depth increases with altitude, as follows:

$$
\mathrm{D}=-52.8+154 \times 10^{-2 *} \mathrm{H}+3 \sin (35.7-\beta)
$$

where: $\mathrm{D}$ is snow depth (in $\mathrm{cm}$ ), $\mathrm{H}$ is altitude (in $\mathrm{m}$ ), $B$ is slope (in degrees).

The analysis of NOAA/TIROS-N, APT, and AVHRR images in recent years indicates that the snow-cover area in the Qilian Mountains decreases from the east to the west and there are two centres of snow cover: one is in Mount Leng Longling and the other is located between Hala Lake and Mount Danghe Nashan.

The beginning of the snow-melt season in the eastern part of the Qilian Mountains is on 5 April, according to data from the weather station there. When the mean daily air temperature is stable above $0^{\circ} \mathrm{C}$, both the snow cover below an altitude of $3700 \mathrm{~m}$ and the river ice begin melting. In May, the $0^{\circ} \mathrm{C}$ isotherm of mean daily air temperature reaches an altitude of $4053 \mathrm{~m}$ and the snow cover melts rapidly. From April to early June is a period for both snow-cover accumulation and melting intensity.

All the seasonal snow cover melts in summer except in the area of the firn basin.
3. CHARACTERISTICS OF SPRING RUN-OFF IN THE MAIN RIVERS IN HEXI REGION

According to an analysis based on observations at 12 hydrometric stations on ten main rivers, the characteristics of spring run-off in the Hexi region can be described as follows:

(1) The amount of spring run-off in the Hexi region (excluding the Sugan Lake basin) is $12.18 \times 10^{8} \mathrm{~m}^{3}$.

(2) The snow-melt run-off is $7.63 \times 10^{8} \mathrm{~m}^{3}$, equal to $62.6 \%$ of the total amount of spring run-off. The values of snow-melt run-off in Shiyang River, Heihe River, and Shule River are $2.46 \times 10^{8} \mathrm{~m}^{3}$, respectively. In addition, the proportion of snow-melt run-off to the amount of spring run-off decreases westward; for example, it is $72.8 \%$ for the Shiyang River basin in the east and $42.8 \%$ for the Shule River in the west.

(3) The major annual change in precipitation in the Qilian Mountains during winter and spring causes major annual variation in spring run-off. The average value of $\mathrm{Cv}$ for spring run-off in Shiyang River, Heihe River, and Shule River is 0.32 , and the $\mathrm{Cv}$ value for snow-melt run-off in spring is 0.41 , about three times as much as that of annual run-off in the Hexi region.

(4) Based on an analysis of square deviations and power spectra, it can be shown that there are several fluctuation periods such as 3, 8, and 15 years in Shiyang River, Heihe River, and Shule River, corresponding to variation in periods (years 3,5 , and 8 ) of precipitation from October to June in the Qilian Mountains. But the variations in spring run-off in the eastern part are not synchronous with those in the western part.

\section{PREDICTION OF SNOW-MELT RUN-OFF}

The spring run-off in the Hexi region is fed by the seasonal snow-melt water in the mountain areas, and secondly by ground water. The variation in spring run-off is determined by winter-spring snow-cover and air-temperature conditions in the Qilian Mountains (Fig.1). A prediction model of spring snow-melt run-off at the Ying Louxia Hydrometric Station (Heihe River) can be constructed by using hydro-meteorological data and snow-cover percentages for the Heihe River basin obtained from NOAA/TIROS-N APT, and AVHRR images.

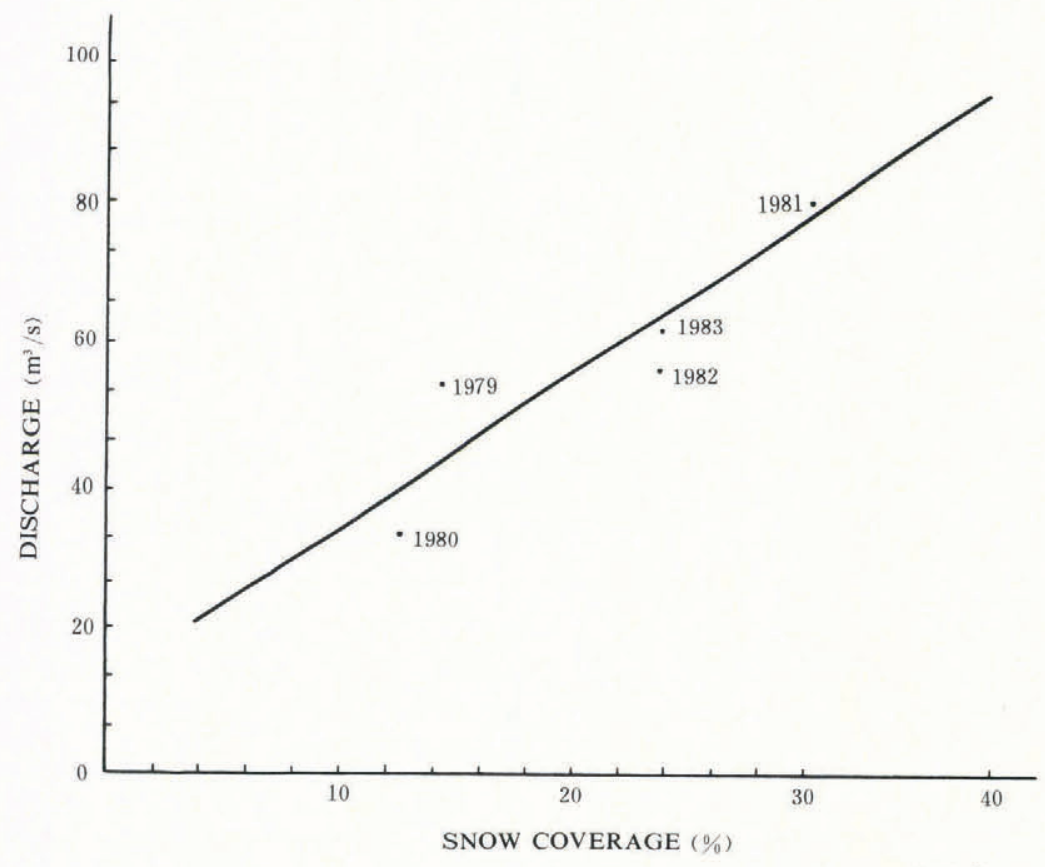

Fig.1. The relationship between snow cover in October and daily mean discharge from April to June at Yingluoxia hydrometric station. 
(1) Daily model

$$
\begin{aligned}
\mathrm{Q}_{\mathrm{n}+1}=\exp \left(1.57+0.08 \mathrm{~T}_{\mathrm{n}}\right. & \left.+0.0165 \mathrm{~S}_{\mathrm{n}}+0.01 \mathrm{P}_{\mathrm{n}}\right)+ \\
& +\left(\mathrm{Q}_{\mathrm{nm}}-\mathrm{Q}_{\mathrm{nc}}\right)^{0.7}
\end{aligned}
$$

$\mathrm{n}$ is date series;

$\mathrm{Tn}$ is mean daily air temperature $\left({ }^{\circ} \mathrm{C}\right)$ at the Qilian Weather Station on $\mathrm{n}$ day;

$\mathrm{Pn}$ is daily precipitation $(\mathrm{mm})$ at the Qilian Weather Station on $\mathrm{n}$ day;

$\mathrm{Sn}$ is snow-cover percentage in the Heihe River basin on $\mathrm{n}$ day

$\mathrm{Q}_{\mathrm{n}+1}$ is mean daily discharge predicted on $\mathrm{n}+1$ day;

$\mathrm{Q}_{\mathrm{nm}}$ is field-measured mean daily discharge on $\mathrm{n}$ day $\left(\mathrm{m}^{3} / \mathrm{s}\right)$

$\mathrm{Q}_{\mathrm{nc}}$ is calculated discharge on $\mathrm{n}$ day $\left(\mathrm{m}^{3} / \mathrm{s}\right)$.

(2) Prediction model for 2 days

$$
\begin{aligned}
& \mathrm{Q}_{\mathrm{n}+2}=\mathrm{Q}_{0}+\left[\mathrm{a}_{0}+\mathrm{a}_{1} \mathrm{~T}_{\mathrm{n}}+\mathrm{a}_{2} \mathrm{~S}_{\mathrm{n}}+\mathrm{a}_{3}\left(\mathrm{P}_{\mathrm{n}}+\mathrm{P}_{\mathrm{n}-1}+\right.\right. \\
& \left.\left.+\mathrm{P}_{\mathrm{n}-2}\right)\right]^{*} \mathrm{~F}\left(\mathrm{~T}_{\mathrm{n}}\right)+\mathrm{Q}_{\mathrm{n}}[1-\exp (-\mathrm{Bt})]
\end{aligned}
$$

where

$\mathrm{Q}_{0}$ is the mean daily base flow;

$a_{0}, a_{1}, a_{2}, a_{3}$ are coefficients;

$\mathrm{Sn}, \mathrm{Tn}, \mathrm{Pn}, \mathrm{P}_{\mathrm{n}-1}, \mathrm{P}_{\mathrm{n}-2}$ are the same as mentioned above;

$\mathrm{F}(\mathrm{Tn})$ is the function of mean daily temperature;

$B$ is the depletion coefficient of water

$$
\left(B=\frac{1}{230} \mathrm{Qn}^{0.79}\right) ;
$$

$t$ is the term of prediction (2 d).

Equations (2) and (3) have been tested by the Water Resources Management Office of the Heihe River basin in the Zhangye and Flood Prevention Office of Gansu Province (Fig.2). The prediction accuracy is suitable for demands.

For an appraisal of the accuracy of Equations (2) and (3), a volume-error equation and a measure of model efficiency $\mathrm{R}^{2}$ have been used, as suggested by J.E. Nash and J.V. Sutcliffe (1970).

$$
\mathrm{Dv}=\frac{\mathrm{Vc}-\mathrm{Vm}}{\mathrm{Vm}}
$$

where

Dv is volume error (\%);

$\mathrm{Vm}$ is measured amount of run-off;

$\mathrm{Vc}$ is calculated amount of run-off;

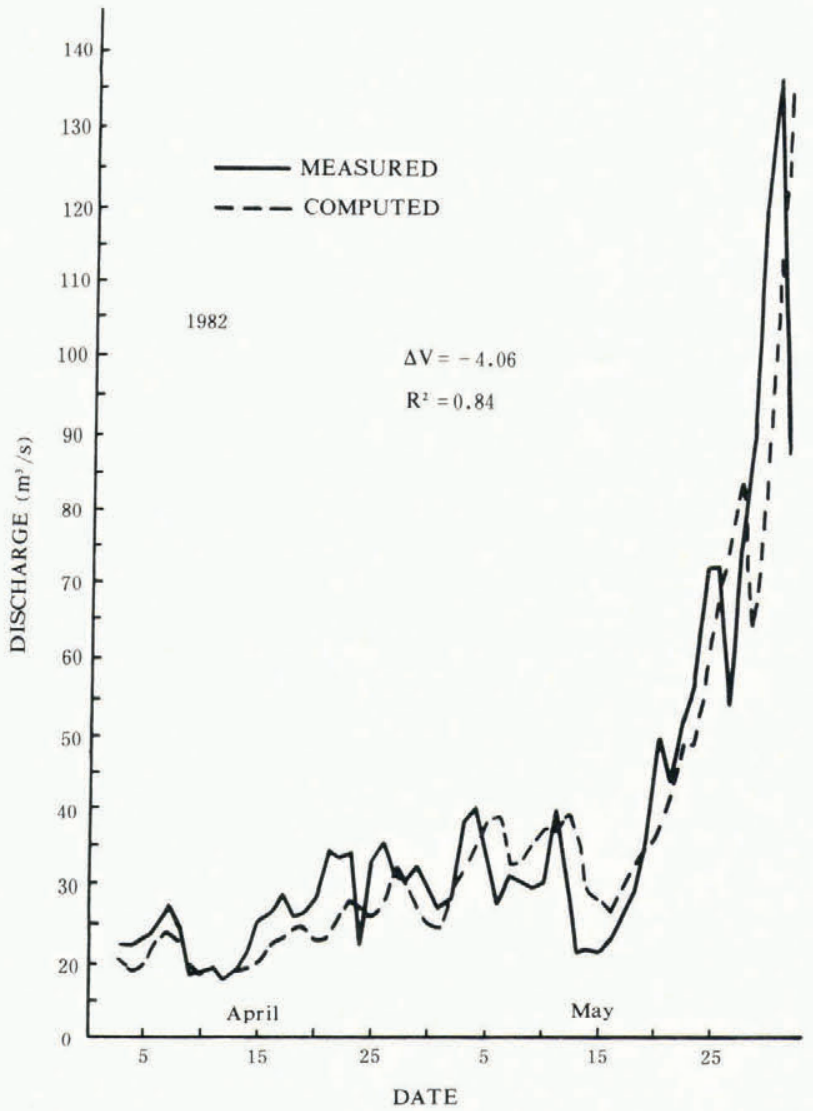

Fig.2. Simulated versus measured stream flow at Yingluoxia hydrometric station from April to May 1982.

$$
\mathrm{R}^{2}=1-\frac{\sum_{\mathrm{i}=1}^{\mathrm{n}}(\mathrm{Qm}-\mathrm{Qc})^{2}}{\sum_{\mathrm{i}=1}^{\mathrm{n}}(\mathrm{QM}-\mathrm{Q})^{2}}
$$

where

$\mathrm{Qm}$ is measured discharge $\left(\mathrm{m}^{3} / \mathrm{s}\right)$;

Qc is calculated discharge $\left(\mathrm{m}^{3} / \mathrm{s}\right)$;

$\mathrm{Q}$ is mean discharge measured during the prediction

\begin{tabular}{|c|c|}
\hline $\begin{array}{c}\text { Model } \\
\text { efficiency } \\
R^{2}\end{array}$ & $\begin{array}{c}\text { Area of } \\
\text { basin } \\
\mathrm{km}^{2}\end{array}$ \\
\hline
\end{tabular}
interval $\left(\mathrm{m}^{3} / \mathrm{s}\right)$.

Table I lists the values of $\mathrm{D}_{\mathrm{y}}$ and $\mathrm{R}^{2}$ for Equations (2)

\begin{tabular}{|c|c|c|c|c|}
\hline $\begin{array}{l}\text { Babao River, China } \\
(1980-84)\end{array}$ & $0.4-15.0$ & $0.81-0.88$ & 2452 & $2590-4700$ \\
\hline $\begin{array}{l}\text { Heihe River Zamashik } \\
\text { station, China } \\
(1980-81)\end{array}$ & 1.7 & 0.85 & 4589 & $2635-4894$ \\
\hline $\begin{array}{l}\text { Heihe River-Ying } \\
\text { Louxia station, } \\
\text { China } \\
(1980-85)\end{array}$ & $(-7.0)-5.0$ & $0.73-0.84$ & 10009 & $1674-4894$ \\
\hline
\end{tabular}
and (3). For comparison, $D_{y}$ and $R^{2}$ from run-off simulations in several other basins are given in Table II. In this

TABLE I. ACCURACY OF SNOW-MELT RUN-OFF FORECASTS FROM EQUATIONS (2) AND (3)

$\begin{array}{ll}\text { Basin } & \text { Volumetric } \\ \text { (simulation } & \text { difference } \\ \text { period) } & \text { Dv }\end{array}$

(\%) $\mathrm{m}$ a.s.l. 


\section{TABLE II. ACCURACY OF SNOW-MELT RUN-OFF FORECASTS IN VARIOUS COUNTRIES*}

\section{Basin}

(simulation

period)

Modry Dul,

Czechoslovakia

Dischma Alps,

Switzerland

Dinwoody, Rocky

Mountains, USA

(1974, 1976)

Bull Lake, Rocky

Mountains, USA

* From A. Rango and J. Martinec (1981).

(\%)

$-0.65$

$\begin{array}{ccl}\begin{array}{l}\text { Model } \\ \text { efficiency }\end{array} & \begin{array}{c}\text { Area of } \\ \text { basin } \\ \mathrm{R}^{2}\end{array} & \begin{array}{l}\text { Elevation } \\ \mathrm{km}^{2}\end{array} \\ & & \end{array}$

$\mathrm{m}$ a.s.l.

0.95

1.32

$1000-1554$

0.83

43.3

$1668-3146$

$1981-4202$

0.82

484

$1970-4185$

case, however, the daily flow for the rivers was computed from the snow-covered areas, temperatures, and precipitation, without corrections for the measured discharge. Therefore, the values of the accuracy criteria are not directly known.

\section{CONCLUSION}

It has been known that mountain snow cover in various climatic regions and at altitudes in the Qilian Mountains has different altitudes of the seasonal snow line and snow-melt conditions, due to variations in precipitation and the heat-exchange processes. Analyses presented here show that the glacier and snow-melt water in the Qilian Mountains is a very important part of the surface-water resource in the Hexi region and the development of agriculture in the Hexi region is strongly influenced by the snow-melt run-off from the Qilian Mountains in the spring.

This work suggests methods which may be used to forecast snow-melt run-off in any basin fed from the Qilian Mountains.

\section{ACKNOWLEDGEMENTS}

The authors gratefully acknowledge assistance from the Meteorological Bureau of Gansu Province in supplying NOAA/TIROS-N APT, and AVHRR images, and from Qiu Guoqing and Mrs Yang Zhenniang for their valuable advice.

\section{REFERENCES}

Nash J E, Sutcliffe J V 1970 River flow forecasting through conceptional models. Part 1. A discussion of principles. Journal of Hydrology 10(3): 282-300

Rango A, Martinec J 1981 Accuracy of snowmelt runoff simulation. Nordic Hydrology 12(4-5): 265-274 